\title{
薄層クロマトグラフィにより分離されたアミノ酸および アマイドの発光分光法による重窒素濃度測定の検討
}

\author{
伊藤 治, 米山忠克, 秋山陽子, 熊沢喜久雄 \\ 東京大学農学部 \\ 東京都文京区弥生1-1-1 \\ 1976年 4 月16日 受理
}

\begin{abstract}
アミノ酸およびアマイドをシリカゲル薄層クロマトグラフィにより分離し，その重窒素濃度を発 光分光分析法により測定する方法についていくつかの検討を行った。その結果シリカゲルからの窒

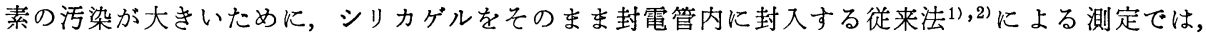

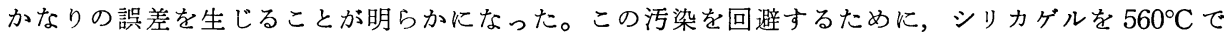
30 分焼き，さらに分離，採取されたシリカゲル中のアミノ酸扰よびアマイドを50\%エタノールで溶 出し，封電管中にはシリカゲルを含まない方法を考案した。これにより窒素の污染量は従来法の $1 / 5$ 程度まで減少した。この方法を植物より分離されたアミノ酸扰よびアマイドの重窒素濃度の測定に 適用した結果，従来法よりもすぐれていることが明らかにされた。
\end{abstract}

\section{1. 緒言}

重窒素の発光分光分析法による測定の普及に伴い, 重窒素の農学, 医学など各分野への利用が急速に高ま っている。発光分光分析法の最大の特徵は, 窒素含量 が $1 \mu \mathrm{g}$ 以下のごく微量の 試料中の 重窒素濃度の 測定 が可能であることといえよう。このため最近ではこの 利点を生かして, 生体中に微量しか存在しない窒素化 合物中への重窒素の取込みを追跡しょうとする試みが 盛んになされている。しかし微量の窒素を取り扱う場 合には，分離操作中に使用する試薬および溶媒，また 大気中に存在する各種窒素化合物からの窒素の混入が 大きな問題となる。筆者らは以前から植物体中におけ るアミノ酸代謝について重窒素をトレーサーとして用 い研究を行ってきた。このさい植物体から分離される アミノ酸の量はきわめて微量であるために, 窒素の污 染による測定値の若干の低下を避けることができなか った。そこで従来法 ${ }^{1)}{ }^{2}$ による測定にさいしての窒素 の污染源と污染量を明らかにし，さらにその污染をよ り少量にくい止める方法を考案したので報告する。

\section{2. 従来法の検討}

従来法においては, 薄層上からかき取ったシリカゲ ル (Merk 社製 Kieselgel G nach Stahl を使用) を そのままガラス管内に封入して放電管を作成したので あるが，シリカゲル中に含まれている窒素が混入し， 值の低下をもたらす可能性が考えられる，そこでこれ による污染量を明確にし, シリカゲルを含むことによ
る測定值の低下の程度を明らかにしようとした。既知 量の重窒素標識のアラニンにシリカゲル $10 \mathrm{mg}$ を加光, 重窒素希釈法により, シリカゲルからの污染窒素量を 求めた。その結果 Table 1 に示すようにシリカゲル $10 \mathrm{mg}$ あたり平均約 $0.17 \mu \mathrm{g}$ の窒素が含まれているこ とがわかった。生体内のアミノ酸のように微量しか分 取し得ない物質を扱うさいには，この量は無視できな い重大なものと考えられる。

実際に 1 種類のアミノ酸とともにかき取られるシリ カゲルは $10 \mathrm{mg}$ 程度であるので, シリカゲル $10 \mathrm{mg}$ あ たりの污染窒素量を $0.167 \mu \mathrm{g}$ と仮定した場合の, 種々 の窒素量および重窒素濃度に捺汓る予想される測定值 を以下に示す計算式により求めた*。

$$
X=\frac{A_{1} W_{1}\left(A_{2}+1400\right)+A_{2} W_{2}\left(A_{1}+1400\right)}{W_{1}\left(A_{2}+1400\right)+W_{2}\left(A_{1}+1400\right)}
$$

$X$ : 試料の重窒素濃度の予想測定值, $A_{1}$ : 試料の重 窒素濃度の理論值, $W_{1}$ : 試料の窒素量, $A_{2}$ : 污染窒 素の重窒素濃度 $(=0.37), W_{2}$ : 污染窒素量 $(=0.167)$

この結果試料窒素量の減少抗よび重窒素濃度の上昇 に伴い, 予想值と理論値の差が広がること, そして重

*試料打よび污染窒素の当量を $M_{1}, M_{2}$ としXを正 確に表現すると $X=\frac{A_{1} M_{1}+A_{2} M_{2}}{M_{1}+M_{2}}$ となる。そし て試料打よび污染窒榇の分子量はそれぞれ $\frac{15 A_{1}+14\left(100-A_{1}\right)}{50}, \frac{15 A_{2}+14\left(100-A_{2}\right)}{50}$ となる から $M_{1}=\frac{100 W_{1}}{A_{1}+1400}, M_{2}=\frac{100 W_{2}}{A_{2}+1400}$ となり， これをさきの式に代入すると, 文中の式が得られ る。 
Table 1 Amount of nitrogen present in silica gel as estimated by an isotope dilution technique

\begin{tabular}{|c|c|c|c|c|c|}
\hline \multirow[b]{2}{*}{$\begin{array}{l}\text { amount of } \\
\text { nitrogen in } \\
\text { alanine } \\
(\mu \mathrm{g})\end{array}$} & \multirow{2}{*}{$\begin{array}{c}- \text { silica } \text { gel }^{\mathrm{a})} \\
{ }^{15} \mathrm{~N} \text { abundance } \\
(\text { atom } \%)\end{array}$} & \multicolumn{2}{|c|}{+ silica gel $^{\mathrm{b})}$} & \multicolumn{2}{|c|}{ +burned silica gel $^{\mathrm{c}}$} \\
\hline & & $\begin{array}{c}{ }^{15} \mathrm{~N} \text { abundance } \\
\text { (atom } \% \text { ) }\end{array}$ & $\begin{array}{l}\text { amount of } \\
\text { nitroger in } \\
10 \mathrm{mg} \text { silica gel } \\
(\mu \mathrm{g})\end{array}$ & $\begin{array}{c}{ }^{15} \mathrm{~N} \text { abundance } \\
\text { (atom \%) }\end{array}$ & $\begin{array}{c}\text { amount of } \\
\text { nitrogen in } \\
10 \mathrm{mg} \text { silica gel } \\
(\mu \mathrm{g})\end{array}$ \\
\hline 2.5 & $30.2 \pm 0.17$ & $28.3 \pm 0.70$ & 0.167 & $29.5 \pm 0.31$ & 0.059 \\
\hline 1.0 & $29.9 \pm 0.24$ & $25.6 \pm 0.61$ & 0.167 & $28.4 \pm 0.65$ & 0.052 \\
\hline 0.5 & $30.0 \pm 0.22$ & $22.8 \pm 0.59$ & 0.157 & $25.0 \pm 0.16$ & 0.099 \\
\hline 0.25 & $29.5 \pm 0.19$ & $17.2 \pm 0.30$ & 0.179 & $23.9 \pm 0.24$ & 0.058 \\
\hline
\end{tabular}

a) Only ${ }^{15} \mathrm{~N}$-labelled alanine was introduced into the discharge tube as the nitrogen compound.

b) $10 \mathrm{mg}$ silica gel was introduced into the discharge tube with ${ }^{15} \mathrm{~N}$-labelled alanine.

c) $10 \mathrm{mg}$ of burned silica gel was introduced into the discharge tube with ${ }^{15} \mathrm{~N}$-labelled alanine.

窒素濃度が 50 atom \%までの範囲内で，5\%以下の誤 差で測定するためには，少なくとも $3 \mu \mathrm{g}$ 以上の窒素を 有するアミノ酸が必要であることが明らかとなった。 この窒素量に相当するアミノ酸を 2 次元展開を行った 薄層上から採取することは非常に困難である。

そこでシリカゲルを $560^{\circ} \mathrm{C} て ゙ 3$ 時間燃焼し，窒素を 除去することを試みた。その結果はTable 1 亿示され るように，污染窒素量は約 $0.07 \mu \mathrm{g}$ と燃焼前の $2 / 5$ に低 下したが，完全には除去することはできなかった。然 焼温度, 燃焼時間をさらに増大させても，污染空素量 はこれ以上減少しなかったので, 燃焼後にるな拈残存 する窒素は, 放電管作成までの間にシリカゲルが吸着 した空気中のアンモニア，硝酸などの窒素化合物およ び窒素ガスなどに由来するものと考えられる。

以上の結果から，放電管内にシリカゲルを封入する かぎり，窒素の污染をこれ以上に低下させることは不 可能であると思われる。そこでより微量のアミノ酸の 重窒素濃度を正確に測定することを目的としてつぎに 述べるような改良法を考案した。

\section{3. 改良法の検討}

\section{$3 \cdot 1$ 放電管作成法}

最も簡便な方法として，Fig.1亿示すような手順で 放電管を作成することを考觉た。まず外径 $4 \mathrm{~mm}$ のパ イレックスガラス管を(a)に示すように細工し，シリカ ゲルを吸い取る。つぎに(b)のように整形し直したのち に, $200 \mu l$ の50\%エタノール溶液でシリカゲル中のア ミノ酸を溶出する。このさい石英綿をつめた凹部の 直ぐ下に穴をあけることにより, 溶出液が自然に落下 できるようにくふらした。溶出が完了したら上部を切 り離し(c), エバポレーターで蒸発乾固させる。これに

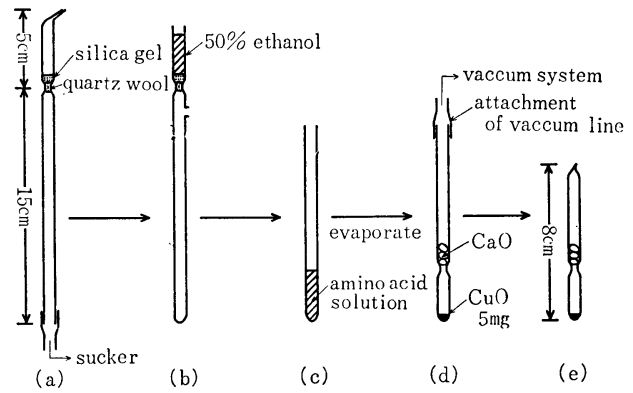

Fig. 1 Preparation procedure of discharge tube for ${ }^{15} \mathrm{~N}$ analysis of amino acids and amides.

酸化銅と酸化カルシウムを入れ，真空装置に取り付け (d), $10^{-4} \mathrm{~mm} \mathrm{Hg}$ 程度に排気したのち, He (10 Torr), $\mathrm{Xe}$ (0.2 Torr) ガスを導入しバーナーで切断する。こ のように作成した放電管(e)は $560^{\circ} \mathrm{C} て ゙ 3$ 時間燃焼し, 一晚放置後測定に供することができる。なおこのさい シリカゲルは,つぎに述べるような理由で污染を最少 限にとどめるために，使用前に $560^{\circ} \mathrm{C}$ で約 30 分燃焼さ せたものを使用する。

\section{$3 \cdot 2$ 窒素の污染}

以上のようにして作成された放電管内には，アミノ

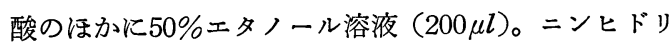
ン, シリカゲルからの溶出物, 酸化銅, 酸化カルシウ ム, $\mathrm{He}, \mathrm{Xe}$ ガスが含まれている。酸化カルシウム, $\mathrm{He}, \mathrm{Xe}$ ガスからの窒素の污染はまったく認められな かったので, ここではそれ以外の物質について, 重窒 素希釈法により窒素量を測定し, 主要な污染源と污染 量を明確にしよらとした。 
Table 2 Amount of nitrogen in ethanol and ninhydrine solution as estimated by isotope dilution technique

\begin{tabular}{c|c|c}
\hline sample & ${ }^{15} \mathrm{~N}$ abundance (atom $\left.\%\right)$ & amount of nitrogen $(\mu \mathrm{g})$ \\
\hline control $^{\mathrm{a}}$ & $30.1 \pm 0.13$ & - \\
$99 \%$ ethanol solution $(200 \mu l)$ & $30.0 \pm 0.35$ & - \\
$50 \%$ ethanol solution $(200 \mu l)$ & $29.3 \pm 0.30$ & 0.0135 \\
distilled water $(200 \mu l)_{\text {control }^{\text {b) }}}$ & $28.5 \pm 0.29$ & - \\
ninhydrin solution $(50 \mu l)$ & $30.0 \pm 0.20$ & 0.0396 \\
\hline
\end{tabular}

a) Only alanine which had $0.5 \mu \mathrm{g}$ nitrogen was introduced into the discharge tube.

b) Only alanine which had $0.25 \mu \mathrm{g}$ nitrogen was introduced into the discharge tube.

Table 2 にタノール溶液とニンヒドリン溶液につ 思われる。

つぎに酸化銅についてであるが，Table 3 に示すと いての結果を示した。50\%エタノール溶液には $100 \mu l$ あたり $0.0067 \mu \mathrm{g}$ の窒素が含まれているが，この窒素 が蒸留水に由来するものであることは，99\%エタノー ル溶液中にはほとんど窒素が含まれないこと，また蒝 留水中には同程度の窒素が含まれることから明らかで ある。再蒸留水中にも蒸留水中とほぼ同じ量の窒素が 含まれているので，水からのこの程度の窒素の污染は 避けられないるのと考兄られる。このため水からの窒 素の污染を最少限にくい止めるには，水の使用量を少 なくするほかないことになるが，アミノ酸の溶出を完 全に行らには， $200 \mu l$ 以上のェタノール溶液が必要で ある。よって溶出のさいには, 溶出液であるェタノ一 ル溶液から $0.014 \mu \mathrm{g}$ 程度の窒素が混入してしまうこと

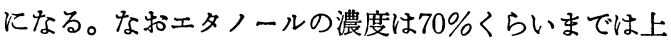
げることができるので，窒素の污染をこの值より幾分 下げることは可能であると思われる。

$0.3 \%$ ニンヒドリン ( $n$-ブタノール溶液) 中にも窒素 の存在が認められるが，ニンヒドリンのスプレイ量は 1 つのスポットあたり最大限 $5 \mu l$ を超えることはな いので，污染量は $0.004 \mu \mathrm{g}$ 以下となり，無規しうると おり然焼させないでそのまま使用した場合には，10 $\mathrm{mg}$ あたり $0.007 \mu \mathrm{g}$ 程度の窒素が含まれているが, $560^{\circ} \mathrm{C}$ で 3 時間焼くことにより，この窒素はほとんど 除去することができる。

Table 3 Decline of ${ }^{15} \mathrm{~N}$ abundance accompanying the increase of the amount of copper oxide (atom \%)

\begin{tabular}{c|c|c|c}
\hline \multirow{2}{*}{ sample } & \multicolumn{3}{|c}{ amount of $\mathrm{CuO}(\mathrm{mg})$} \\
\cline { 2 - 4 } & 5 & 10 & 20 \\
\hline $\begin{array}{l}\text { non-burned } \mathrm{CuO} \\
\text { burned } \mathrm{CuO}^{\mathrm{a}}\end{array}$ & $30.1 \pm 0.21$ & $29.9 \pm 0.16$ & $29.5 \pm 0.16$ \\
\hline
\end{tabular}

a) $\mathrm{CuO}$ was burned at $560^{\circ} \mathrm{C}$ for 3 hours.

シリカゲル中には窒素が含まれていることは， Table 1 から明らかであるが, 溶出のさいにこのうち のどのくらいが出てくるかが重要な問題である。この 結果はTable 4 に示すように, シリカゲル $10 \mathrm{mg}$ あた り約 $0.053 \mu \mathrm{g}$ の窒素が溶出されてくることがわかっ た。これはシリカゲルに吸着されているアンモニア,

Table 4 Amount of nitrogen in the eluate from silica gel by $50 \%$ ethanol solution

\begin{tabular}{|c|c|c|c|c|c|c|}
\hline & \multirow{3}{*}{$\begin{array}{c}-\operatorname{silica}^{a)} \\
\text { gel }\end{array}$} & \multicolumn{4}{|c|}{+ silica gel $^{\mathrm{b})}$} & \multirow{3}{*}{$\begin{array}{c}\text { + silica gel } \\
\text { after } \\
\text { development }^{\mathrm{c}}\end{array}$} \\
\hline & & \multicolumn{4}{|c|}{ burning time (min) } & \\
\hline & & 0 & 30 & 90 & 180 & \\
\hline${ }^{15} \mathrm{~N}$ abundance (atom $\%$ ) & $30.2 \pm 0.21$ & $27.3 \pm 0.51$ & $29.3 \pm 0.23$ & $29.3 \pm 0.06$ & $29.3 \pm 0.08$ & $28.4 \pm 0.72$ \\
\hline $\begin{array}{l}\text { amount of nitrogen in the eluate } \\
\text { from } 10 \mathrm{mg} \text { silica gel }(\mu \mathrm{g})\end{array}$ & - & 0.0527 & 0.0152 & 0.0152 & 0.0152 & 0.0314 \\
\hline
\end{tabular}

a) Only ${ }^{15} \mathrm{~N}$-labelled alanine which had $0.5 \mu \mathrm{g}$ nitrogen was introduced into the discharge tube.

b) $10 \mathrm{mg}$ silica gel was introduced into the discharge tube with ${ }^{15} \mathrm{~N}$-labelled alanine.

c) Silica gel, which was scraped from thin-layer plate after two dimensional chromatography, was introduced into the discharge tube. 
硝酸などの可溶性物質に由来するものと思われる。ま た $560^{\circ} \mathrm{C} て ゙ 30 ， 90 ， 180$ 分間燃焼したのち，直ちに溶出 を行らと, 溶出窒素量は $0.015 \mu \mathrm{g}$ に減少する。この窒 素量は溶出のさいに使用するエタノール溶液中に含ま れるものとほぼ一致するので，シリカゲルに由来する ものではないと言える。よって $560^{\circ} \mathrm{C}, 30$ 分以上の然 焼により, シリカゲルより溶出される窒素は除去され らると考光られる。つぎに $560^{\circ} \mathrm{C} て ゙ 30$ 分間焼いたシリ カゲルで薄層をつくり，1 次元フェノール：水 $(75 ：$ $25 \mathrm{v} / \mathrm{v}), 2$ 次元 $n$-ブタノール:䣷酸: 水 $(4: 1: 1 \mathrm{v} /$ $\mathrm{v} / \mathrm{v}$ ) で展開したのちのシリカゲルから溶出されてく る窒素量を測定してみた。その結果はTable 5 亿示 すように：シリカゲルは $10 \mathrm{mg}$ あたりにして $0.0179 \mu \mathrm{g}$ （0.0314-0.0135）の窒素を燃焼後のこれらの操作の間 にふたたび吸着してしまらことがわかった。米山ら” は, 展開, 乾燥中に和壮る窒素の污染の重大さを示唆 し，その予防手段として二重の展開槽を使用すること を提案している。本実験の結果も，この操作中におけ る窒素の污染が見逃せない注どに大きいものであるこ とを示している。よって展開。乾燥を行うさいには, 細心の注意とくふうをすることが必要であろう。

以上の結果から, 本法に扒いて大きな窒素の污染を もたらす原因は，溶出のさいに使用するエタノール溶

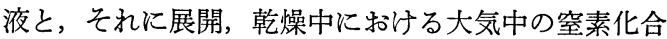
物の吸着であると考学られる。そしてその量はそれぞ れ $0.0135 \mu \mathrm{g}, 0.0179 \mu \mathrm{g}$ となり, 合計で $0.0314 \mu \mathrm{g}$ 程 度であると推定される。そこでつぎに，0.0314 $\mu \mathrm{g}$ の 窒素が污染すると仮定した場合の予想される測定值と 実測値との比較を行ってみた。この結果をTable 5 に 示す。溶出法の場合，スポットした窒素がすべて溶出 されてくるわけではないので，予想值を正確に求める ためには，溶出窒素量を知る必要がある。そこでこれ を重窒素希釈法により求めた結果, 溶出率は平均で66 \%となっていた。つぎに拈のおのの溶出窒素量におけ るシリカゲル無添加の場合の重窒素濃度を求める必要 がある。これを窒素量と重窒素濃度との関係を実験的 に求めた Fig. 2 から推定すると, Table 6 の第 3 行の

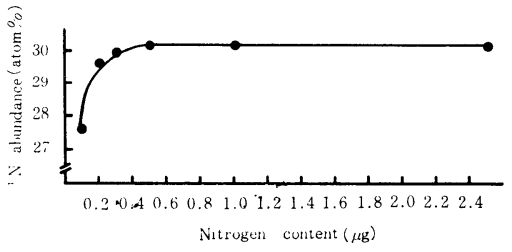

Fig. 2 Correlation between nitrogen content and ${ }^{15} \mathrm{~N}$ abundance.

ようになる。以上の值から前述の式を使って計算され た予想值は，実測值と非常に良く一致している。この ことは，さきに別個に明らかにした窒素の污染が，実 際の測定のときにも複合された形で正確に反映してい ることを示して扮り，污染窒素量の推定が妥当であっ たことを示唆している。

つぎに污染窒素量を $0.0314 \mu \mathrm{g}$ ，アミノ酸の溶出率を $66 \%$ と仮定した場合の，種々の窒素量および重窒素濃 度に括ける予想される測定値を従来法の検討の場合と 同様にして求めた結果，本法により重窒素濃度が50\% 以下のアミノ酸試料について，95\%以上の精度で測定 するためには，1 $1 \mu \mathrm{g}$ 以上の窒素が必要であることが わかった。従来法では $3 \mu \mathrm{g}$ 以上であったことを考慮 すると, 本法はより少量のアミノ酸試料とついての測 定を可能にしたと言らことができる。

\section{4. 測 定 例}

重窒素標識硫安を供与したヒマワリ葉から分離され た数種のアミノ酸についての測定結果を, 従来法と改 良法とを比較してTable 6 に示す。アミノ酸は 2 次元

Table $6{ }^{15} \mathrm{~N}$ abundance in amino acids and amide isolated from sunflower leaves (atom \%)

\begin{tabular}{l|c|c|c}
\hline & $\begin{array}{c}\text { relative } \\
\text { amount }\end{array}$ & $\begin{array}{c}\text { previous } \\
\text { method }\end{array}$ & $\begin{array}{c}\text { improved } \\
\text { method }\end{array}$ \\
\hline aspartic acid & ++ & 4.40 & 4.78 \\
glutamic acid & ++++ & 4.29 & 4.76 \\
glutamine & ++ & 15.9 & 18.0 \\
alanine & + & 3.50 & 3.65 \\
$\begin{array}{l}\gamma \text {-aminobutyric } \\
\text { acid }\end{array}$ & + & 4.23 & 4.31 \\
\hline \multicolumn{3}{r}{}
\end{tabular}

Table 5 Comparison between calculated values and values determined by the improved method

\begin{tabular}{l|c|c|c|c}
\hline amount of nitrogen spoted on silica gel $(\mu \mathrm{g})$ & 0.25 & 0.50 & 1.0 & 2.5 \\
amount of nitrogen eluted from silica gel $(\mu \mathrm{g})$ & 0.14 & 0.37 & 0.68 & 1.67 \\
${ }^{15} \mathrm{~N}$ abundance estimated from Fig. 2 (atom \%) & 28.6 & 30.1 & 30.2 & 30.2 \\
calculated values $^{\mathrm{a}}$ (atom \%) & 23.3 & 27.7 & 28.9 & 29.6 \\
determined values (atom \%) & $23.5 \pm 0.25$ & $27.4 \pm 0.28$ & $28.8 \pm 0.35$ & $30.2 \pm 0.26$ \\
\hline
\end{tabular}

a) Calculated supposing that $0.0314 \mu \mathrm{g}$ was contaminated from eluate of $10 \mathrm{mg}$ silica gel. 
のシリカゲル薄層クロマトグラフィにより分離した が，シリカゲルは $560^{\circ} \mathrm{C} て ゙ 30$ 分間焼いたものを使用し た。アミノ酸の分離状況は，焼かないシリカゲルを使 用した場合とほぼ同程度であり, 使用にさいしては問 題はないと考兄られる。改良法はシリカゲルを封電管 内に封入する従来法に比べ，いずれのアミノ酸につい ても高い値を与えている。とくにグルタミンに関して は顕著な值の改善が認められる。しかしアラニン, $\gamma$ アミノ酪酸のように少量しか存在しないアミノ酸で

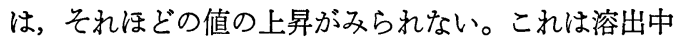
に窒素が損失し，Fig. 2 に示したような測定值が急激 に低下する範囲（窒素量 $0.1 〜 0.2 \mu \mathrm{g}$ ）にはいてしまっ たことによると考光られる。このように改良法におい ては，窒素の損失といらことがあるために，極微量し か存在しないアミノ酸の場合には, 值がか党って低下 してしまう恐れがあることに留意しなければならな w。

グルタミン，アスパラギンはその分子中に窒素を 2 分子有し，しかもアミド基のほうは温度や $\mathrm{pH}$ の上昇 により容易にはずれてしまう。このためこれらの重窒 素濃度を測定する場合には温和な条件で分離，放電管 作成などの操作を進めないと, 正確な值を得ることが できない3)。そこでアミド基を重窒素で標識したグル タミンを用い，従来法による水の追い出し操作のさい の温度が測定値に及ぼす影響を調べた。その結果は Table 7 亿示されるように，温度の上昇に伴い著しい 値の低下が認められた。一方改良法では濃縮のさいの

Table $7{ }^{15} \mathrm{~N}$ abundance in glutamine* (atom \%)

\begin{tabular}{c|r|r|r|r}
\hline \multirow{2}{*}{$\begin{array}{c}\text { improved } \\
\text { method }\end{array}$} & \multicolumn{4}{|c}{ previous method } \\
\cline { 2 - 5 } & $120^{\circ} \mathrm{C}^{\mathrm{a}}$ & $160^{\circ} \mathrm{C}$ & $200^{\circ} \mathrm{C}$ & $240^{\circ} \mathrm{C}$ \\
\hline 25.7 & 24.4 & 21.2 & 19.2 & 13.4 \\
\hline
\end{tabular}

* Glutamine which was labelled with ${ }^{15} \mathrm{~N}$ in the amide group was used.

a) The temperature in heating with a small muffle to eliminate the water and absorbed gases. $40^{\circ} \mathrm{C}$ 以上に温度を上げることはないので，より高い值 が得られる。このように改良法では，アマイドに関し てより精度の高い測定ができるという特徵があること がわかった。

\section{5. 総 括}

シリカゲル薄層クロマトグラフィにより分離された アミノ酸扣よびアマイド中の重窒素濃度を測定する場 合の測定精度を明確にするために，窒素の污染源技よ び污染窒素量を明らかにするとともに，污染窒素量を さらに減少させ測定精度を向上させるための方法につ いても検討した。その結果つぎのようなことが明らか となった。

1）窒素の污染はシリカゲルからのものが最も多 く，その量はシリカゲル $10 \mathrm{mg}$ あたり $0.17 \mu \mathrm{g}$ であっ た。

2）シリカゲルからの窒素の污染を避けるために， シリカゲルを $560^{\circ} \mathrm{C}$ で30分焼き，さらに分離，採取さ れたシリカゲル中のアミノ酸およびアマイドを $50 \%$ エ タノールで溶出し，封電管中にはシリカゲルを含まな い方法を開発した。その結果シリカゲル $10 \mathrm{mg}$ あたり 污染空素量は $0.03 \mu \mathrm{g}$ まで減少した。

3）この改良法を用いて植物体中より分離されたア ミノ酸扣よびアマイドの重窒素濃度を測定した結果, 従来法よりも精度高く測定できること，とくにグルタ ミンのようなアマイドに関しては，この効果が顕著で あることがわかった。

アミノ酸执よびアマイド以外の物質で，いままで窒 素量が微量であるために重窒素の応用が不可能であっ た物質の重窒素濃度の測定に本法を適用するならば， 重窒素の利用がさらに広まるものと考兄られる。

\section{文献}

1） 米山忠克，熊沢喜久雄：土肥誌，43，262(1972）

2) H. Kano, T. Yoneyama, K. Kumazawa: Anal. Biochem., 67, 327 (1975)

3）有馬泰紘，熊沢喜久雄：土肥誌，46，355(1975) 


\title{
Abstract
}

\section{Examination of Emission Spectrometric ${ }^{15} \mathrm{~N}$ Analysis of Amino Acids and Amides Separated by Thin Layer Chromatography}

\author{
Osamu Ito, Tadakatsu Yoneyama, Yoko AkIYAma and \\ Kikuo KUmAZAwA \\ Faculty of Agriculture, University of Tokyo, \\ 1-1-1, Yayoi, Bunkyo-ku, Tokyo
}

\begin{abstract}
The method to determine the ${ }^{15} \mathrm{~N}$ abundance in amino acids and amides, which were separated by thin layer chromatography, was examined. It was found that the previous method $^{1,2)}$, in which silica gel was introduced into the discharge tube, made the serious error in the determination because of the heavy contamination of nitrogen from silica gel. The simple method was designed in order to avoid this contamination by burning silica gel at $560^{\circ} \mathrm{C}$ for 3 hours and washing away amino acids and amides with $50 \%$ ethanol from silica gel. This method diminished the contamination of nitrogen up to $1 / 5$ of the previous method. The ${ }^{15} \mathrm{~N}$ abundance in amino acids and amides isolated from plant tissues was determined by this method, and consequently it was made clear that this method was superior to the previous method.

(Received April 16, 1976)
\end{abstract}

